Környezetegészségügy - Eredeti közlemény / Environmental health - Original article

Magyar Donát', Páldy Anna', Szigeti Tamás', Szilágyi Alexandra², Orlóci László,4

${ }^{7}$ Nemzeti népegészségügyi Központ, Budapest - National Public Health Center, Budapest

2 Szent István University, Department of Nature Conservation and Landscape Ecology, Eger - Szent István Egyetem, Természetvédelmi és Tájökológiai Tanszék, Eger

${ }^{3}$ Eötvös Loránd Tudományegyetem, Botanikuskert, Budapest - Eötvös Loránd University, Botanical Garden, Budapest

${ }^{4}$ Magyar Díszkertészek Szövetsége, Budapest - Hungarian Ornamental Horticulturist Association, Budapest

\title{
A potenciális allergenitás felhasználási lehetösége a zöldterületek minösítésében és az allergén terhelés szabályozásában
}

\author{
The application of potential allergenicity in the \\ evaluation of urban green spaces and regulation of \\ allergen exposure
}

\section{Összefoglalás}

Az egyes növényfajok, taxonok allergenitása alapján kiszámítható, hogy az egyes városi zöldterületek, parkok vagy fasorok esetén milyen mértékű a pollenterhelés. A városi parkok minősítésére külföldön már alkalmazott I ${ }_{\text {UczA }}$ módszert hazai parkok és vonalas létesítmények fásszárú növényzetén teszteltük. 
Az eredmények azt mutatták, hogy a módszer megfelelően alkamazható parkoknál, azonban a vonalas létesítményeknél nem, mivel ez utóbbiaknál a számítás alapját képező terület meghatározási módszer nincs egyértelmüen megadva. A számítási módszer által megkövetelt növénymorfológiai adatok a nyílvánosan elérhető hazai fakataszterek ( $n=11)$ csupán 20\%-ában állnak rendelkezésre. A továbbiakban egy általunk kidolgozott új módszert mutatunk be, amely a jogi alkalmazás igényeit is kielégíti, ugyanakkor könnyen végrehajtható a már meglévő fakatasztereken, mert növénymorfológiai adatokat nem igényel, hanem az allergén fák százalékos aránya alapján ad minősítést. Eszerint alacsony allergén kibocsátású a zöldterület, ha a fa és cserje egyedek kevesebb, mint 10\%-a tartozik a potenciálisan erősen/nagyon erősen allergén taxonok közé; közepes, ha 11-34\%, magas, ha 34\% feletti ezen egyedek aránya. Emellett bemutatjuk a módszer alkalmazásának lehetőségét a zöldterületek allergén pollen kibocsátásának csökkentésére, amelyet elsősorban szabályozás révén, közterületek vonatkozásában lehetne megvalósítani.

Kulcsszavak: allergia, pollen, allergenitás, zöldterület, városi környezet

\section{Abstract}

Based on the allergenicity of each plant species and taxa, the allergen potential of urban green areas can be calculated. We have tested the I UczA method already used abroad for the qualification of urban parks. Tests have confirmed that the method is suitable for parks. However, we have found that it is not suitable for the evaluation of tree lines, as the calculation method of area of tree lines is not clearly specified. The plant morphological data required by the calculation method are available in only $20 \%$ of the Hungarian tree cadastres (publicly available databases $N=17$ ). In the following, we have developed a 
new, robust evaluation method that satisfies the needs of legal application. This method gives a rating based on the percentage of allergen trees in a given public area. According to this, a green area has a low, medium or high allergen emission if $<10 \%, 71-34 \%$, or $>34 \%$ of the tree individuals are belonging to the category of high/very high potential allergenicity, respectively. In addition, we present the possibility of the legal application of the above method to reduce allergen pollen emissions of green areas, as well as the content requirements of a draft regulation.

Keywords: allergy, pollen, allergenicity, urban green areas, legislation

\section{EGÉSZSÉGTUDOMÁNY}

2020;64(4): 57-80

\section{HEALTH SCIENCE}

Közlésre érkezett: 2020. október 29.

Submitted: 29 October 2020

Elfogadva: 2020. november 30 .

Accepted: 30 November 2020

Levelezési cím/Correspondence:

Dr. Magyar Donát

Nemzeti Népegészségügyi Központ 1097 Budapest, Albert Flórián út 2-7.

E-mail: magyar.donat@gmail.com

$$
\text { Tel.: +36 } 1 \text { 476-1100/2210 }
$$




\section{Bevezetés, célkitűzés}

A városokban található pollenadó fák jelentős allergén terhelést okozhatnak. Ennek ellenére a városi zöldterületek tervezése és fenntartása során az allergológiai tényezőt legtöbbször nem veszik figyelembe; az elmúlt évtizedekben a kialakítást elsődlegesen kertészeti (föként környezeti és növényvédelmi) és gazdasági szempontok határozták meg. Az allergiás megbetegedések számának növekedésével azonban a nem megfelelően kialakított zöldterületek lehetséges kedvezőtlen egészséghatására is felfigyeltek. A pollent szóró fák ültetésének visszaszorítására több eszköz is kínálkozik. Egyrészt, a kertész szakembereknek meg kell ismerniük az egyes fafajok, fajták és kertészeti változatok (továbbiakban taxonok) allergén pollenadó képességét, és ezt a tényezőt is figyelembe kell venniük a zöldterületek kialakítása és fejlesztése során. Másrészt, tájékoztatni kell a lakosságot különféle kiadványokkal, a kertészkedőknek szóló újságcikkekkel, vagy az allergológiai rendelőkbe kifüggesztett plakátokkal. Érdemes törekedni a vásárlói tudatos- ság kialakítására is, amelyre külföldi faiskolai árudákban, kertészeti lerakatoknál már bevett példa az allergénmentes facsemeték felcímkézése. Azonban átfogóbb változást a zöldterületek kialakítását és fenntartását célzó rendeletek módosításától remélhetünk. Míg a lakosságot és a vásárlókat megszólító üzenetekkel a magánkertek növényzetének összetételére gyakorolhatunk hatást, addig a jogszabályok segítségével a nagyobb területeket lefedő, egységesen kezelt zöldterületek (a közterületeken található növényzet) allergénkibocsátása szabályozható. A szabályozás alapja a zöldterület allergén pollen terhelésének felmérése, amelyet az egészségtudatos tervezés, fenntartás követ. Munkánk célja áttekinteni a zöldterületek allergológiai értékelésére alkalmas módszereket, ezek tesztelési eredményeit, amelyek alapján kiválasztjuk a megfelelő módszert, amelyet elsősorban egészségügyi szakemberek, kerttervezők és tájépítészek figyelmébe ajánlunk. Célunk továbbá meghatározni a zöldterületek allergénterhelése szempontjából elfogadható célértéket. Tanulmányunkban bemutatjuk az al- 
lergén terhelés csökkentésére irányuló javaslatokat is.

\section{A zöldterületminősítő módszer kidolgozásának szempontjai}

A zöldterületek felmérésére kiválasztott módszernek az alábbi gyakorlati elvárásoknak kell megfelelnie:

- A már meglévő adatbázisokra építkezik,

- Nem jelent jelentős többletfeladatot vagy költségeket,

- Könnyen elvégezhető,

- Objektív módszer, amely alkalmas arra, hogy egy későbbi szabályozás alapját képezze.

Egy adott zöldterület allergén terhelésének megállapítására megfelelő módszernek túnhet a légköri pollenkoncentráció müszeres mérése. Azonban zöldterületek, parkok, fasorok egyedi allergén kibocsátásának méréséhez számos pollencsapda összehangolt múködtetésére volna szükség, amelyre ritkán adódik lehetőség, emellett egy ilyen vizsgálat nagyon költséges és nehezen kivitelezhető lenne. Emellett zavaró tényezőként jelentkeznének a nagy távolságról érkező pollenszemek. A helyi allergénforrások felmérését más módon is el lehet végezni, mégpedig modellszámítások segítségével ${ }^{1,2}$. A parkok allergén kibocsátásának becslésére alkalmas modellekben a növényzet kiterjedését és összetételét súlyozzuk allergenitásuk szerint. A modellek figyelembe vehetnek még további változókat, pl. a fatörzs, vagy korona legfontosabb dendrometriai változóit, amelyek tovább finomíthatják az eredményt. Parkok esetében a jól kidolgozott I UczA Urban Green Zone Allergenicity Index 1) modell áll a rendelkezésünkre, amelynek alkalmazására számos példa található a nemzetközi szakirodalomban.

E modell a hazai zöldterület minősítésre is megfelelő módszernek ígérkezett. A módszerrel kétféle zöldterület típusban, parkokban és fasorokban folytattunk teszteket, amelyek eredményeit az alábbiakban ismertetjük. 


\section{Az I $\mathrm{IuZz}_{\text {modell tesztelése }}$ parkokban}

Az eredetileg a mediterrán térség városi parkjainak minősítésére kidolgozott I ucza modell egy hányados révén fejezi ki a vizsgált városi zöldterület allergizáló hatásának mértékét. A modell a minősítendő területen található valamenynyi növényfaj minden egyes példányának a potenciális allergenitási értékét súlyozza az egyedek biometrikus paramétereivel, majd ezeket összegzi. Ezt követően a modell összeveti az eredményt egy azonos méretü, de maximális allergén terheléssel bíró hipotetikus területre kiszámítható értékkel ?. Az $I_{\text {UCZA }}$ modell szerinti hányados értéke 0 és 1 között helyezkedhet el, ahol a 0 a „nem allergizáló” területet jelenti, míg az 1 azon hipotetikusan, vagy adott ritka esetben létező legmagasabb allergén potenciált, amely esetben a vizsgált területet „maximálisan allergizálónak”

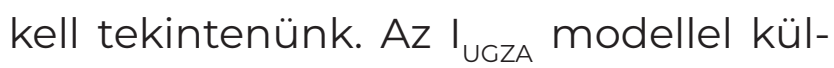
földön, elsősorban Spanyolországban és Lengyelországban számos parkot vizsgáltak. Hazai kipróbálásra a Nemzeti Népegészségügyi Intézet egyik épüle- tekkel közre zárt, tehát jól lehatárolható zöldterületét vizsgáltuk meg. A vizsgált helyszín területe 1207,6 m²; amelyen 17 fa, ill. cserjefaj 48 egyede található, amelyek többsége keleti tuja (19 db), emellett előfordul az oregoni hamisciprus (8 db), a nyugati tuja (6 db), a tiszafa (4 db), különbözö fenyőfélék (összesen 4 db) valamint páfrányfenyő, babérmeggy, korai juhar és nyír egy-egy példánya. A cserjeszint és a gyep növényzete: terülő boróka, sóskaborbolya, kerti madárbirs, tűztövis, kerti gyöngyvessző, borostyán, közönséges falgyom, nagy csalán, pázsitfüfélék. A fás növényzetről katasztert készítettünk, majd az egyedeket besoroltuk a fajra megadott potenciális allergenitási kategóriába (Potential Allergenic Value, a továbbiakban: PAV, Cariñanos és mtasi ${ }^{2}$, Samson és mtsai ${ }^{3}$ alapján). Az így kapott eredménytérképeket az 1. és a 2. ábrán mutatjuk be. 


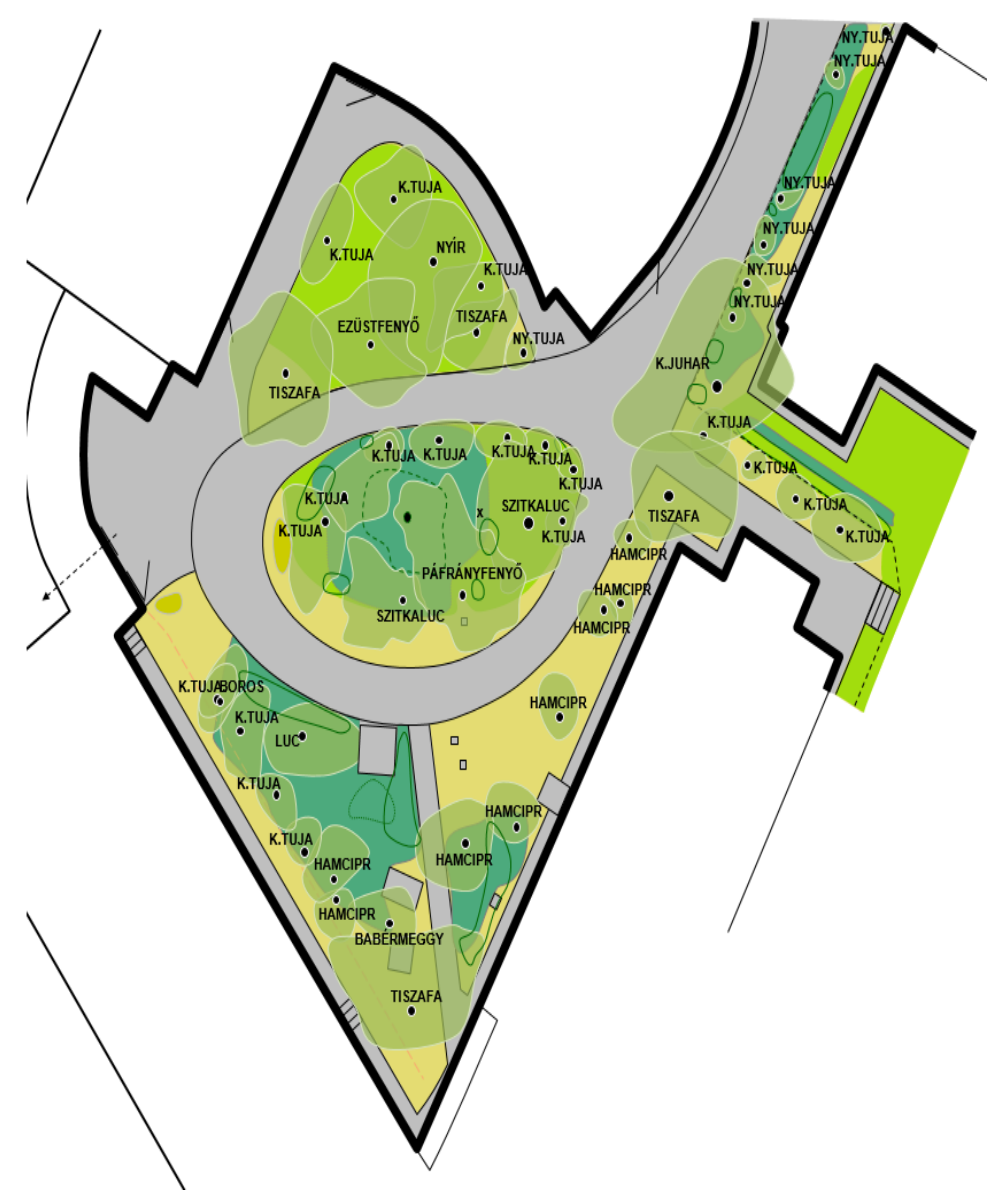

1. ábra: A vizsgált park növényzetéröl készült kataszter térképes ábrázolása. A térképen jelölt fák: K.JUHAR: korai juhar (Acer platanoides), K.TUJA: keleti tuja (Platycladus orientalis), NY.TUJA: nyugati tuja (Thuja occidentalis), NYíR: közönséges nyír (Betula pendula), HAMCIPR: oregoni hamisciprus (Chamaecyparis lawsoniana), TISZAFA: közönséges tiszafa (Taxus baccata), LUc: közönséges lucfenyő (Picea abies), SzITKAluc: szitka luc (Picea sitchensis), EZüstFenYő: szúrós luc (Picea pungens), PÁfrÁNYFENYŐ: páfrányfenyő (Ginkgo biloba), BABÉRMEGGY: balkáni babérmeggy (Prunus laurocerasus). Figure 1. Map of the cadastre and visualization of the vegetation of the investigated park. Trees shown on the map: K.JUHAR: Norway maple (Acer platanoides), K.TUJA: Chinese thuja (Platycladus orientalis), NY.TUJA: northern white cedar (Thuja occidentalis), NYíR: silver birch (Betula pendula), HAMCIPR: Port Orford cedar (Chamaecyparis lawsoniana), TISZAFA: yew (Taxus baccata), LuC: Norway spruce (Picea abies), sZITKALUC: Sitka spruce (Picea sitchensis), EZÜSTFENYÖ: Blue spruce (Picea pungens), PÁFRÁNYFENYŐ: ginkgo (Ginkgo biloba), BABÉRMEGGY: cherry laurel (Prunus laurocerasus). 


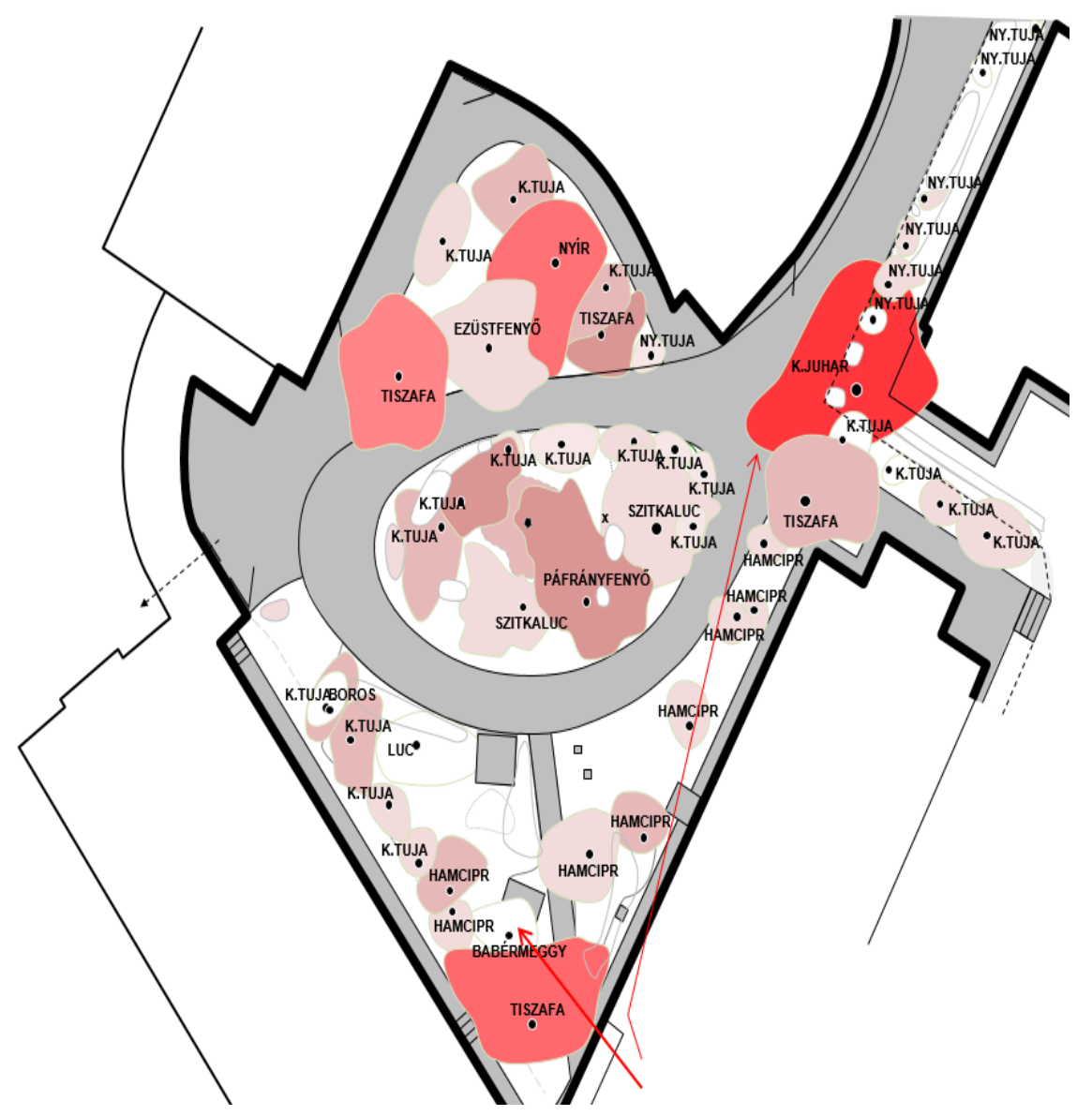

2. ábra: A vizsgált területen található fák potenciális allergenitása (PAV ²) és lombkorona vetülete. A nyilak a potenciálisan legmagasabb és a legalacsonyabb allergén pollenkibocsátású fákat jelölik. Figure 2. Potential Allergenic Value ${ }^{2}$ and crown projection of trees in the study area. Arrows show the pollen emitting trees of strongest and lowest potential allergenicity.

A vizsgált terület I ${ }_{\text {ucza }}$ modell szerint számított allergén terhelése 0,2, amely közepesnek tekintehető (Cariñanos és mtsai (2017). I ucza $_{\text {index 0,30-as }}$ értéke felett az allergiások tüneteket tapasztalhatnak; az index maximuma 1). Ugyanakkor az is megállapítható, hogy az allergén terhelést alacsony szintüre (0,15-re) lehetne csökkenteni mindössze azáltal, ha két föbb pollenadó faegyedet (a korai juhart és a nyírfát) ugyanolyan méretű hipoallergén fára cserélnék. (Fontos megjegyeznünk, hogy a fák kivágását nem javasoljuk, azonban ha arra egyéb okból sor kerül, a helyükre ne allergén pollenadó fákat ültessenek). 


\section{Az I $\mathrm{UCZA}_{\text {modell }}$ tesztelése vonalas létesítményeknél}

Mint azt korábban említettük, az I modell parkok minősítésére készült. Vonalas létesítmények, fasorok allergén pollenadó képességére nem áll rendelkezésünkre modell. Kézenfekvő ugyanakkor, hogy kipróbáljuk az $\mathrm{I}_{\mathrm{uczA}}$ modell alkalmazhatóságát fasorok esetében is. E tesztekhez hipotetikus fasorokat állítottunkössze, amelyek a leggyakrabban előforduló eseteket képviselik. A számítások eredményeit a 1. táblázat foglalja össze. Az alapfelvetés egy házsorok által határolt „útkanyon”, amelyben egy egysoros vagy dupla fasoros telepítés van. A terület legyen egyszerú téglalap, területe így a hossz és a szélesség szorzataként könnyen számolható. Azonban a számítás többféle módon végezhető. Az itt bemutatott, fasorokra vonatkozó tesztek a vonalas létesítmények területszámítása során felmerülő lehetséges változatokat mutatják be. Az útkanyon hosszát tekintsük minden esetben azonosnak. Ahol a különbség jelentkezik, az a vizsgált terület szélessége, amely lehet a maximális lombkorona szélesség (1. és 4. próba) vagy az útkanyon szélessége (2. és 3. próba). Adódik még egy lehetőség a területszámításra, ahol az út- és a lombkorona szélesség összegét vesszük (5. próba).

A számítások alapján látható, hogy az I ${ }_{\text {UczA }}$ modell nagyon érzékeny a különféle terület lehatárolási módszerekre, ugyanis az egyes tesztek eredményei jelentős eltérést mutatnak. Ha csak a lombkorona szélességgel (a „valós zöldfelülettel") számolunk, magas allergén terhelést $(0,47)$ kapunk, míg ugyanott, ha az útkanyon szélességét (a közterület méretét, illetve a „valós hatóterületet") vesszük alapul, alacsony értéket $(0,09)$ ad a modell. Dupla fasornál ez az ingadozás szintén jelentős $(0,19-0,47)$, míg az 5. teszt eredménye $(0,31)$ e kettő 
között helyezkedik el.

1. táblázat: Az $\mathrm{I}_{\mathrm{UczA}}$ modell tesztjei hipotetikus fasorokon.

Table 1. Tests of $I_{U G Z A}$ on hypothetical tree lines.

\begin{tabular}{|c|c|c|c|c|c|c|c|c|}
\hline & & $\begin{array}{l}\text { 1. próba } \\
1^{\text {st }} \text { test }\end{array}$ & $\begin{array}{l}\text { 2. próba } \\
2^{\text {nd }} \text { test }\end{array}$ & $\begin{array}{l}\text { 3. próba } \\
3^{\text {rd }} \text { test }\end{array}$ & $\begin{array}{l}\text { 4. próba } \\
4^{\text {th }} \text { test }\end{array}$ & & $\begin{array}{l}\text { 5. próba } \\
5^{\text {th }} \text { test }\end{array}$ & \\
\hline TA szélessége (m) & BAC width (m) & 5 & 25 & 25 & 10 & & 15 & \\
\hline TA hossza (m) & BAC length (m) & 50 & 50 & 50 & 50 & & 50 & \\
\hline TA területe $\left(\mathrm{m}^{2}\right)$ & BAC area $\left(\mathrm{m}^{2}\right)$ & 250 & 1250 & 1250 & 500 & & 750 & \\
\hline lugza érték & lugza value & 0.47 & 0.09 & 0.19 & 0.47 & & 0.31 & \\
\hline fajszám & $\begin{array}{l}\text { number of tree } \\
\text { species }\end{array}$ & 2 & 2 & 2 & 2 & & 2 & \\
\hline fafajok & tree species & P.c. & F.e. & F.e. & P.c. & F.e. & P.c. & F.e. \\
\hline egyedszám (db) & number of trees & 5 & 5 & 10 & 10 & 12 & 10 & 12 \\
\hline allergenitási fok* & $\begin{array}{l}\text { allergenic } \\
\text { potential* }\end{array}$ & 1 & 1 & 1 & 1 & 3 & 1 & 3 \\
\hline pollenkibocsátás* & pollen emission* & 3 & 3 & 1 & 1 & 3 & 1 & 3 \\
\hline $\begin{array}{l}\text { virágzási } \\
\text { időtartam (hét) }\end{array}$ & $\begin{array}{l}\text { principal } \\
\text { pollination period } \\
\text { (weeks) }\end{array}$ & 15 & 15 & 15 & 8 & 15 & 8 & 15 \\
\hline $\begin{array}{l}\text { virágzási } \\
\text { időtartam, } \\
\text { kategória* }\end{array}$ & $\begin{array}{l}\text { principal } \\
\text { pollination } \\
\text { period, category* }\end{array}$ & 3 & 3 & 3 & 3 & 3 & 3 & 3 \\
\hline $\begin{array}{l}\text { lombkorona } \\
\text { vetület }\left(\mathrm{m}^{2}\right)\end{array}$ & $\begin{array}{l}\text { horizontal crown } \\
\text { projection }\left(\mathrm{m}^{2}\right)\end{array}$ & 25 & 25 & 25 & 25 & 25 & 25 & 25 \\
\hline magasság (m) & tree height (m) & 10 & 10 & 10 & 10 & 10 & 10 & 10 \\
\hline
\end{tabular}

P.c.: Pyrus communis (világoszöld kör), F.e. Fraxinus excelsior (sötétzöld kör). Szürke sáv: gyalogosok, kerékpárosok által használt út; fehér sáv: autóút, ill. egyéb közterület, vonalazott terület: a területszá- 
mítás alapját képező rész (a továbbiakban: TA). *: Cariñanos és mtasi alapján². 1. próba: egy fasoros út, TA szélessége=lombkorona szélesség; 2. próba: egy fasoros út, TA szélessége=útkanyon szélessége; 3. próba: dupla fasoros út, TA szélessége=útkanyon szélessége; 4. próba: dupla fasoros út, TA szélessége=lombkorona szélessége; 5. próba: dupla fasoros út, TA szélessége=lombkorona szélessége + gyalogosok, kerékpárosok által használt út szélessége. Látható, hogy a TA meghatározása erősen befolyásolja az I ${ }_{\text {UczA }}$ modell által kifejezett allergén kibocsátás értékét.

P.c.: Pyrus communis (light green circles), F.e. Fraxinus excelsior (dark green circles). Gray strip: pedestrian or bike path; white strip: roadway, other public area; lined area: the basis of the area calculation (in the followings: BAC). *: Cariñanos et al. ${ }^{\text {st }}$ test: single tree line, BAC width=crown width; $2^{\text {nd }}$ test: single tree line, BAC width = the width of street canyon; $3^{\text {rd }}$ test: double tree line, BAC width= the width of street canyon; $4^{\text {th }}$ test: double tree line, BAC width= crown width; $5^{\text {th }}$ test: double tree line, BAC width= crown width + roadway width. Apparently, the definition of BAC strongly influences the

$I_{\text {UczA }}$ value, expressing allergenic potential of urban green spaces.

A vonalas létesítmények esetében

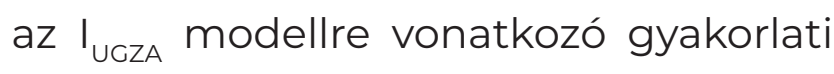
teszteket a budapesti kerékpárutakat övező fasorokon végeztük ${ }^{4}$. A megvizsgált kerékpárúti fasorok összesen 2355 faegyede mintegy 60 taxonba sorolhatók be. Ezek közül 10 taxon (17\%) tekinthető erősen allergénnek. Nagyobb arányban előforduló allergén taxonok a kőrisek, a platánok és a zöld juhar, míg a nyír-, éger-, füz- és tölgyfajok csak színező elemként jelennek meg. A fák fele tartozik erősen allergén taxonba, ez 1175 db példányt jelent. Közepes allergenitással a fák 31\%-a bír (732 db). E valós terepi körülmények között elvégzett vizsgálattal, az elméleti tesztekkel egybehangzó eredményre jutottunk, nevezetesen arra, hogy a I UczA $_{\text {modell csak }}$ a jól körülhatárolt, önálló zöldterületek esetén alkalmazható. A terepi vizsgálatok során további módszertani buktatók is nyílvánvalóvá váltak. A hipotetikus fasorokon végzett tesztnél alkalmazott ideális környezet (a házak által közrezárt útkanyon) a gyakorlatban ritkán fordul elő. Valós helyzetekben a terület legtöbbször azért nem adható meg egyértelműen, mert a) a lombkorona 
vetület nem képez folytonos területet (pl. beültetetlen fahelyek miatt, vagy nagyon eltérő lombkorona szélességú fákból álló fasornál); b) az „útkanyon” nem definiálható. Ez utóbbira példa a változó szélességú úttest, illetve az egyvagy kétoldali házsor hiánya (közterek, útkereszteződések, kanyarok, stb. esetében). E pontokon a területhatár kijelölése bizonytalanná válik.

Leszögezhetjük tehát, hogy fasoroknál nem alkalmazható a módszer (szemben a parkok minősítésével, mivel ezek kiterjedése jól meghatározható, és így a területszámítás egyértelmüen elvégezhető). A vonalas létesítmények, fasorok, utcák, kerékpárutak esetében a határok kijelölése sokszor kérdéses, és nem végezhető el egyértelmú szabályok mentén, következésképpen egyazon területre akár több I uczA $_{\text {rték is }}$ megadható, amelyek széles határok között ingadozhatnak. Mindezek alapján könnyen belátható, hogy a gyakorlatban a terület megítélése számos hibalehetőség forrása lehet, és szinte elkerülhetetlenek a szubjektív döntések, ezért az értékelés önkényessé válhat. Amennyiben ennek a kiküszöbölésére törekednénk, bonyolult szabályrendszer kidolgozása válna szükségessé, amely a gyakorlati alkalmazást aránytalanul megnehezítené. A fentiek alapján egy egyszerüsített eljárást javaslunk. A négyzetméterben kifejezett területi adat alkalmazását elvetjük, helyette pedig út szakaszhatárokat (keresztutak által meghatározott közterületi egységeket) adunk meg.

\section{A fakataszterek használata a zöldterületek minősítésében}

A zöldterületi adatbázisok, a közterületi fák nyilvántartási rendszerei, a fakataszterek kiváló lehetőséget adnak a faállomány összetételének vizsgálatára, amely viszonylag gyorsan és nagy területre végezhető, emellett a változások is jól nyomon követhetőek ${ }^{5}$. Kézenfekvő, hogy a zöldterületek allergológiai minősítéséhez a már meglévő fakatasztereket vegyük alapul. A potenciális allergenitás értékei könnyen összekapcsolhatók a fakataszter adat- 
bázisokkal ${ }^{6}$. A fakataszterek elkészítését sok országban hatályos törvények írják elő; ez alól hazánk sem kivétel. Magyarországon a fakataszterek elkészítését az önkormányzatok tulajdonában lévő ingatlanvagyon nyilvántartási és adatszolgáltatási rendjéről szóló 147/1992 (XI. 6.) kormányrendelet írja elő. A fakataszterekben tárolt adatok típusai azonban nem egységesek, mint azt az általunk beszerzett kataszterek adattípusait bemutató 2 . táblázatban láthatjuk. A táblázatból az is látható, hogy

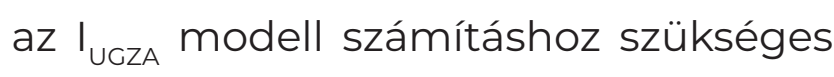
lombkorona vetület adatot csak kevés (20\%) fakataszteri adatbázis tartalmazza. Ugyanakkor a fakataszterek elkészítése során bizonyos alapvető adattípusok felvételére törekedni kell. Szaller ${ }^{7}$ szerint a törvényi előírásnak megfelelő, legegyszerúbb fakataszter adattartalma: a fa jelölése térképen vagy helyszín- rajzon, a fa azonosítója, koordinátái, a fa terület-meghatározás alapú jelölése, település/kerület, fasor/park, szakasz/ tömb, oldal/tábla, fa sorszáma, helyrajzi azonosító (HRSZ, házszám), a fa egyedi paraméterei: fafaj, törzsátmérő, koronaátmérő, famagasság, törzsmagasság, valamint a fa állapotfelmérésére vonatkozó egyéb adatok, védettség, kezelési javaslatok; a kataszter felvételének ideje, a felvételező neve). A zöldterületek allergológiai szempontból történő minősítéséhez a legfontosabb adatok a fafaj neve (magyarul és/vagy latinul) és darabszáma, amelyet valamennyi kataszter tartalmaz. Ezekkel az adatokkal tehát mindegyik kataszterben kiszámítható a zöldfelület minősítésre használható legegyszerúbb érték, az adott területen ill. útszakaszokon található allergén fajok százalékban kifejezett aránya. 


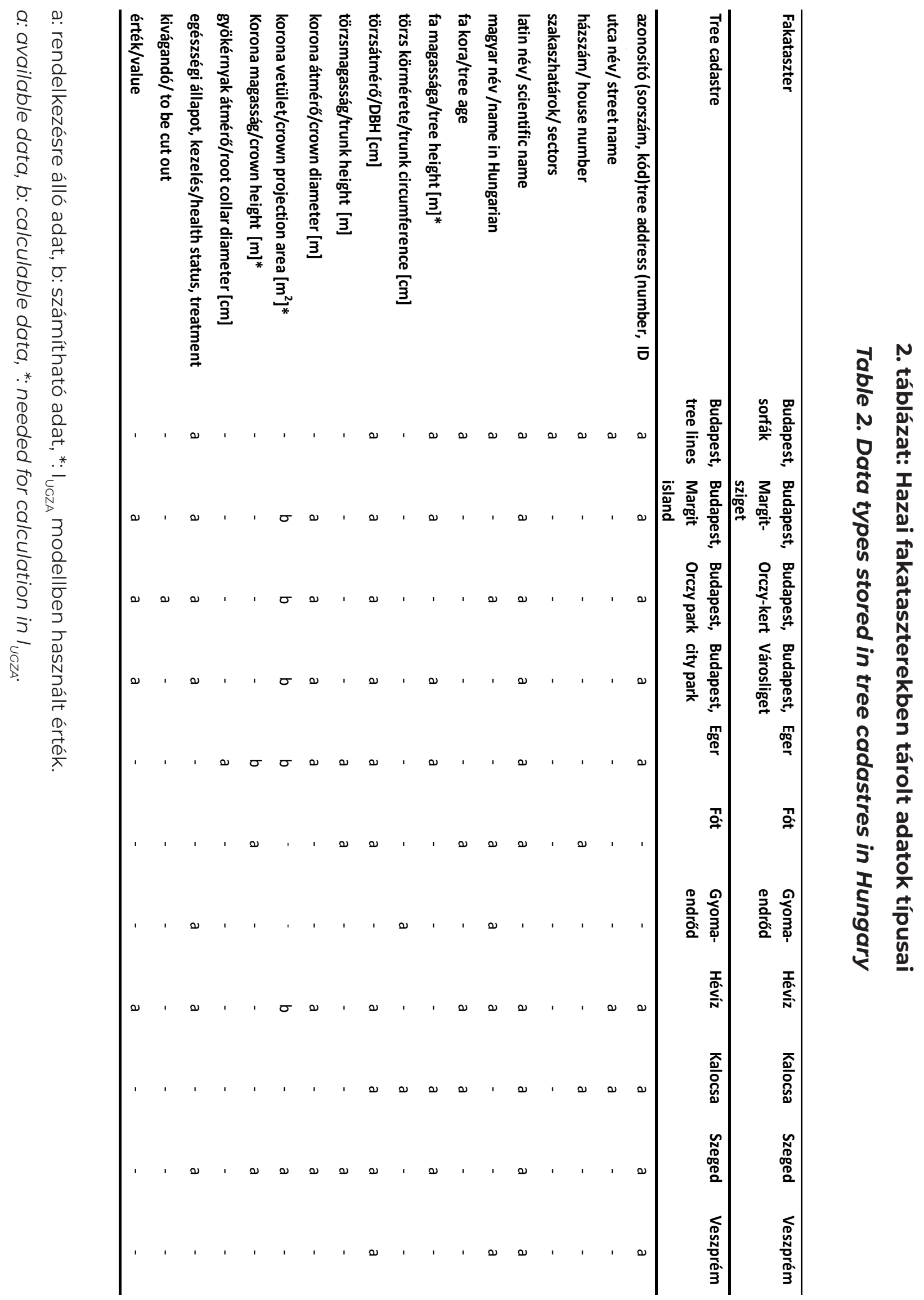




\section{Zöldterület minösítés - módszertani javaslat}

A fenti megállapításokat összegezve arra a megállapításra jutottunk, hogy

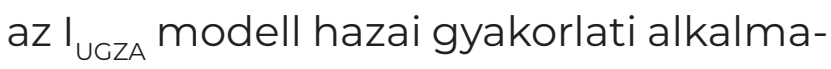
zásának komoly korlátokat szabnak az alábbi tényezők

a) a modellszámításhoz szükségs lombkorona vetületet csak kevés (20\%) fakataszteri adatbázis tartalmazza;

b) vonalas létesítmények esetén a terület lehatárolása legtöbb esetben nem végezhető el egyértelmüen.

c) a modellben használt, az egyes növényfajokra vonatkozó allergén érték (Potential Allergenic Value (PAV) 1,2,4) nem tartalmaz megfelelő referenciákat az allergenitás alátámasztására, ezért támadható egy esetleges jogvitában.

Az I korlátai miatt a zöldterület minősítés és szabályozás céljára egy kevésbé érzékeny zöldterület minősítési eljárást dolgoztunk ki. Ebben a park vagy fasor területe helyett a közterületi névvel azonosított területre számítjuk ki a zöldte- rület allergenitási értékét, amelyben az I $_{\text {uczA }}$ index helyett a különböző potenciális allergenitással rendelkező faegyedek arányával számolunk. A potenciális allergenitást a PAV helyett a CARE-S értékkel számítjuk ki ${ }^{8}$. A célértéket az I UczA által meghatározott értékekből számítjuk át. Az eljárás lépéseit az alábbiakban ismertetjük. Cariñanos és mt-

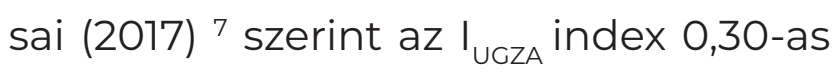
értéke felett az allergiások tüneteket tapasztalhatnak az adott zöldterület pollenkibocsátásának következtében.

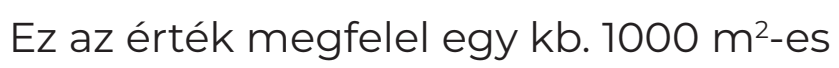
parknak, ahol a $10 \mathrm{~m}$ magas és $3 \mathrm{~m}$-es sugarú lombkorona vetülettel rendelkező fák 35\%-a erősen allergén.

A zöldterület minősítés lépései az alábbiak:

1.) A minősítendő terület kijelölése:

- park esetén a park közterületi elnevezésével (pl. Városliget), vagy geokoordinátákkal és/vagy térképes megjelöléssel azonosítható a terület

- utak, utcák, kerékpárutak, és más vonalas létesítmények esetén a minősítendő terület lehet egy közterületi sza- 
kasz (pl. két keresztutca által közrezárt útszakasz) vagy a teljes közterület.

2.) A területen előforduló fákról és cserjékről katasztert készítünk (a felvételre javasolt adatok: a fa magyar és/vagy latin neve, lehetőség szerint, ill. új telepítésnél a kertészeti változat megadásával; a fa helye (pl. GPS koordináta), amely egyben a darabszámot is megadja. A potenciális allergenitás érték (CARE-S) egyes növénytaxonokra vonatkozóan az interneten ${ }^{9}$, valamint a Közterületi Sorfák Jegyzékében hozzáférhető.

3.) A fakataszter alapján eredménytérképet állítunk elő, amelyen az egyes fák és cserjék potenciális allergenitását a megadott színkóddal jelöljük.

4.) A zöldterület minősítés: ennek során a különböző potenciális allergenitással rendelkező faegyedek arányát kiszámítjuk.
Alacsony allergén kibocsátású a terület, ha a faegyedek kevesebb, mint 10\%-a az erős/nagyon erős potenciális allergenitású kategóriába tartozó fa és cserje egyedek aránya;

közepes, ha 11-34\% az erős /nagyon erős potenciális allergenitású kategóriába tartozó fa és cserje egyedek aránya;

magas allergén kibocsátású, ha 34\% feletti az erős /nagyon erős potenciális allergenitású kategóriába tartozó fa és cserje egyedek aránya. A magas allergén kibocsátású terület kifogásolt minősítést kap. A zöldterület minősítés folymatát a 3. ábrán is bemutatjuk. 

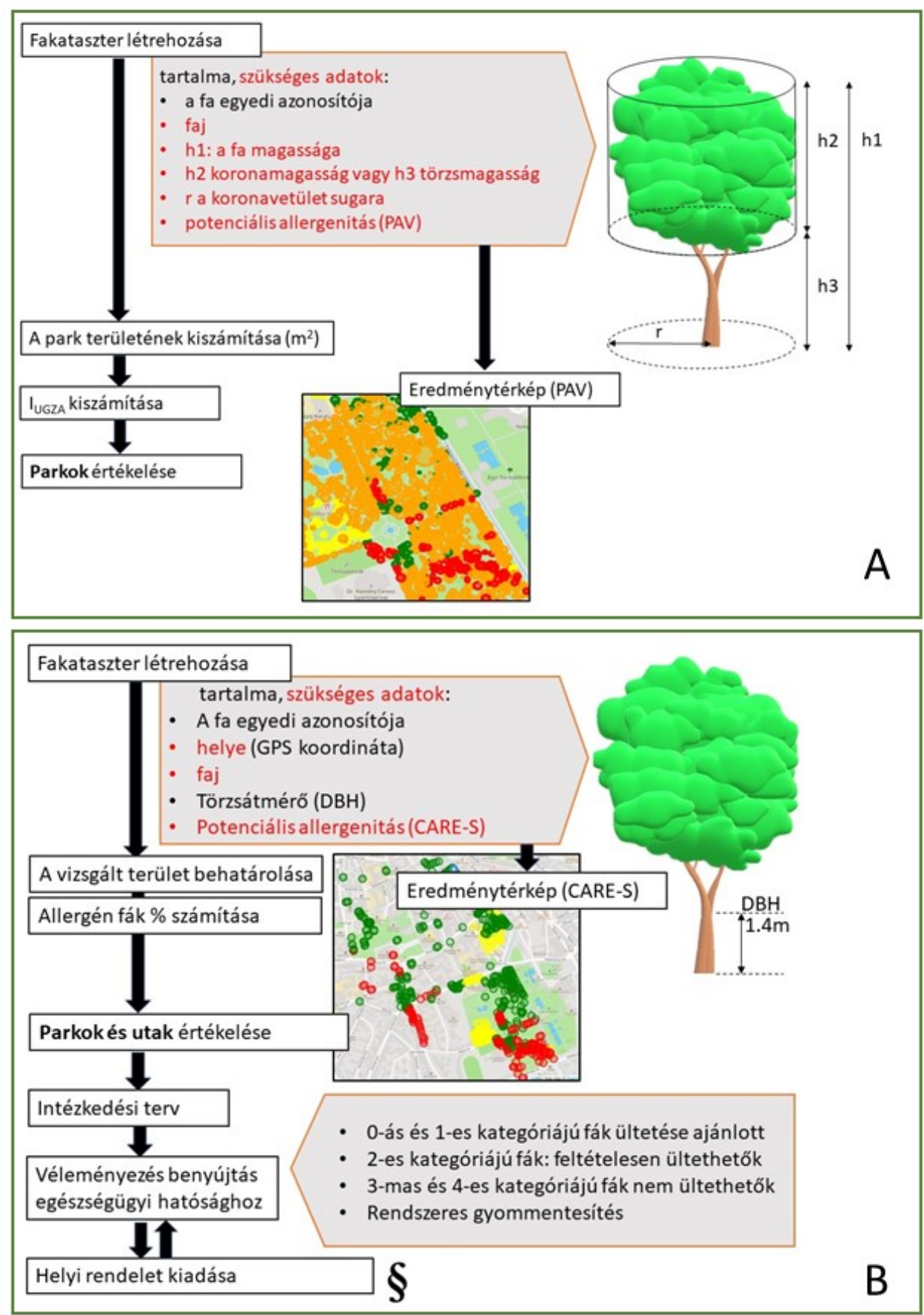

3. ábra: A zöldterület minősítés folyamata. A: I UczA módszer szerint B: az új módszer szerint, amelynek révén, a javasolt további intézkedésekkel a zöldterületek allergén pollen kibocsátása csökkenthető. 

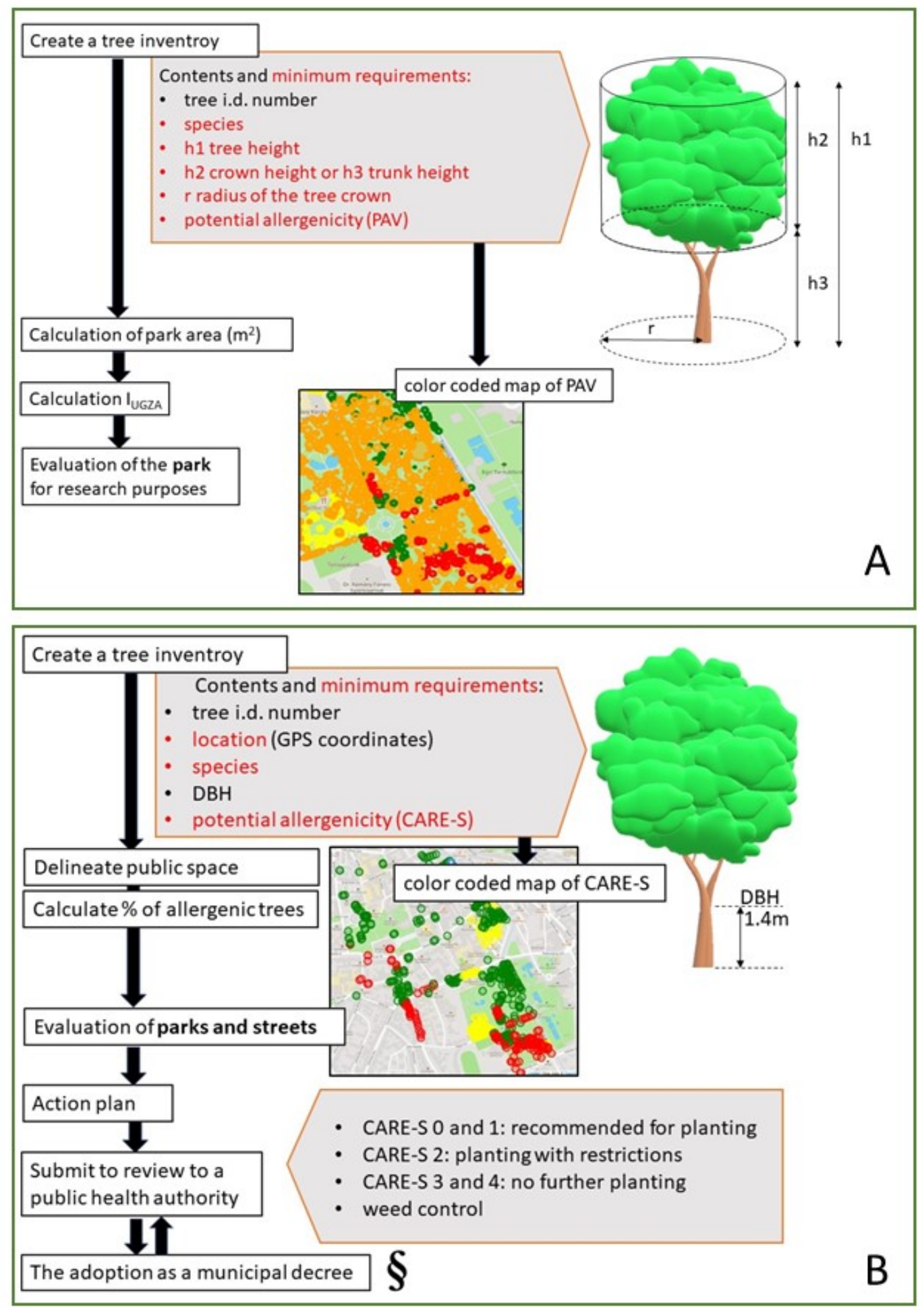

Figure 3. The evaluation process of green areas. A: according to the IUcZA method B: according to the new method, through which the proposed additional measures can reduce the emission of allergen pollen in urban green areas. 


\section{A potenciális}

allergenitás alkalmazása

a zöldterületek allergén pollen kibocsátásának csökkentésére

A pollen kibocsátó zöldterületek felmérésére alkalmas rendszer kidolgozása révén a növényzet fajösszetételéből és aerobiológiai tulajdonságaiból megadhatóvá válik az egyes meglévő vagy tervezett zöldterületek allergén pollen kibocsátási potenciálja. Az ajánlott módszer felhasználható a várostervezés növényzet-telepítési gyakorlatában, és akár új elemként is megjelenhet a zöldterület-tervezés szabályozásában, ahol egy adott faj, vagy változat allergenitását is figyelembe kell venni a hagyományosan értékelt szempontok (pl. várostürés) mellett.

Virágzásuk idején a pollenadó fák jelentős mértékben hozzájárulhatnak az allergénterheléshez. Könnyü belátni, hogy e fák (egyéb okból történő) eltávolítása és nem allergizáló fafajokkal való cseréje alacsonyabb allergénterhelést eredményez. Az allergén pollenkibocsá- tás csökkentése érdekében tehát nem kell mást tenni, mint figyelembe venni a telepítendő fajok allergenitását a városi zöldterületek tervezésénél.

Ültetésre elsősorban a nem allergén vagy kis mértékben allergén fajokat javasoljuk (0-ás és 1-es kategória).

A mérsékelten allergén fajok (CARE-S 2-es kategória) telepítése bizonyos korlátozásokkal továbbra is folytatható, mivel az allergén pollenadó taxonok nem zárhatók ki teljes mértékben a közterületekről a biológiai diverzitás megőrzése érdekében. A lecsökkent biodiverzitás révén megnövekedne a növényállományok sérülékenysége ${ }^{10}$. Belterületen e fajok telepítése esetén az elegyarányuk a telepítési ponttól (az új fa ültetésének helyétől) számított 200 m sugarú körben max. 10\% (a 200 m-es távolságot Skjøth és mtsai "számításai alapján adtuk meg). A mérsékelten allergén fák és cserjék közül a hazánkban gyakori nemzetségekbe (Carpinus, Fraxinus, Morus, Populus) tartozó fajok csak kis mennyiségben ültethetők a te- 
lepüléseken. Összefüggő állományok, fasorok telepítése kerülendő az ún. védett területeken: a sürün lakott vagy nagy forgalmú területeken, iskolák, óvodák, bölcsődék, nyugdíjas otthonok, szabadtéri sportlétesítmények, egészségügyi ellátórendszer létesítményei 200 m-es körzetében, valamint gyógyhely minősítésű területeken. Kétlakiság esetében csak a női ivarú egyed választható. Ajánlott a hosszú távú cseréjük O-ás vagy 1-es kategóriájú fajokra. A mérsékelten allergén fák és cserjék közül a hazánkban még nem meghonosodott fák és cserjék (Cupressus, Olea, Ostrya) ültetése kerülendő.

Az erősen és nagyon erősen allergén (3-mas és 4-es kategóriába sorolt) fák és cserjék további ültetése belterületen kerülendő. Már meglévő fák kivágása nem javasolt, viszont a hosszú távú cseréjük ajánlott nem allergizáló (0-ás és 1-es kategóriájú) fajokra. A közterületi sorfák jegyzékében e kategóriáknál az alábbi megjelölés szerepel: „közegészségügyi szempontból kerülendő az ültetése." A besorolást a Nemzeti Népegészségügyi Központ végzi, amelyet a
Magyar Díszkertészek Szövetsége hoz nyílvánosságra. A jegyzéket a szakemberek rendszeresen felülvizsgálják és frissítik.

Az alkalmazásra példaként Eger belvárosáról előállított eredménytérképet mutatunk be a 4. ábrán ${ }^{12}$. A térkép a fent ismertetett módszer használatával a Treebase programmal készült. Az egri elemzést lakossági kérdőíves felméréssel egészítették ki. A beérkezett kérőóvek ( $n=126)$ alapján a válaszadók többsége szerint sokan látogatják a város zöldterületeit, ugyanakkor úgy vélik, hogy szükséges a város zöld környezetének jelenlegi állapotát javítani. Mind a zöldterületek számát, mind arányát kevesli a lakosság. A válaszadók érdeklődtek az őket körülvevő városi zöld környezet minősége és mennyisége iránt, valamint nyitottak voltak a produktívabb területhasználatra. Az allergiás válaszadók többségét csak időszakosan (szezonálisan) hátráltatja fa pollenallergiája a szabadidős tevékenységek gyakorlásában. A felmérésben megkérdezett pollenallergiás válaszadók közel egyharmada ( $n=13)$ gondolja 
úgy, hogy az allergén fák cseréje változtatna a zöldterületeken töltött idejének mennyiségén, és ezzel életminőségén. hogy a városi zöld környezetre vonatkozó szemléletformáló tevékenységekre is szükség van.

A felmérés alapján megállapítható,

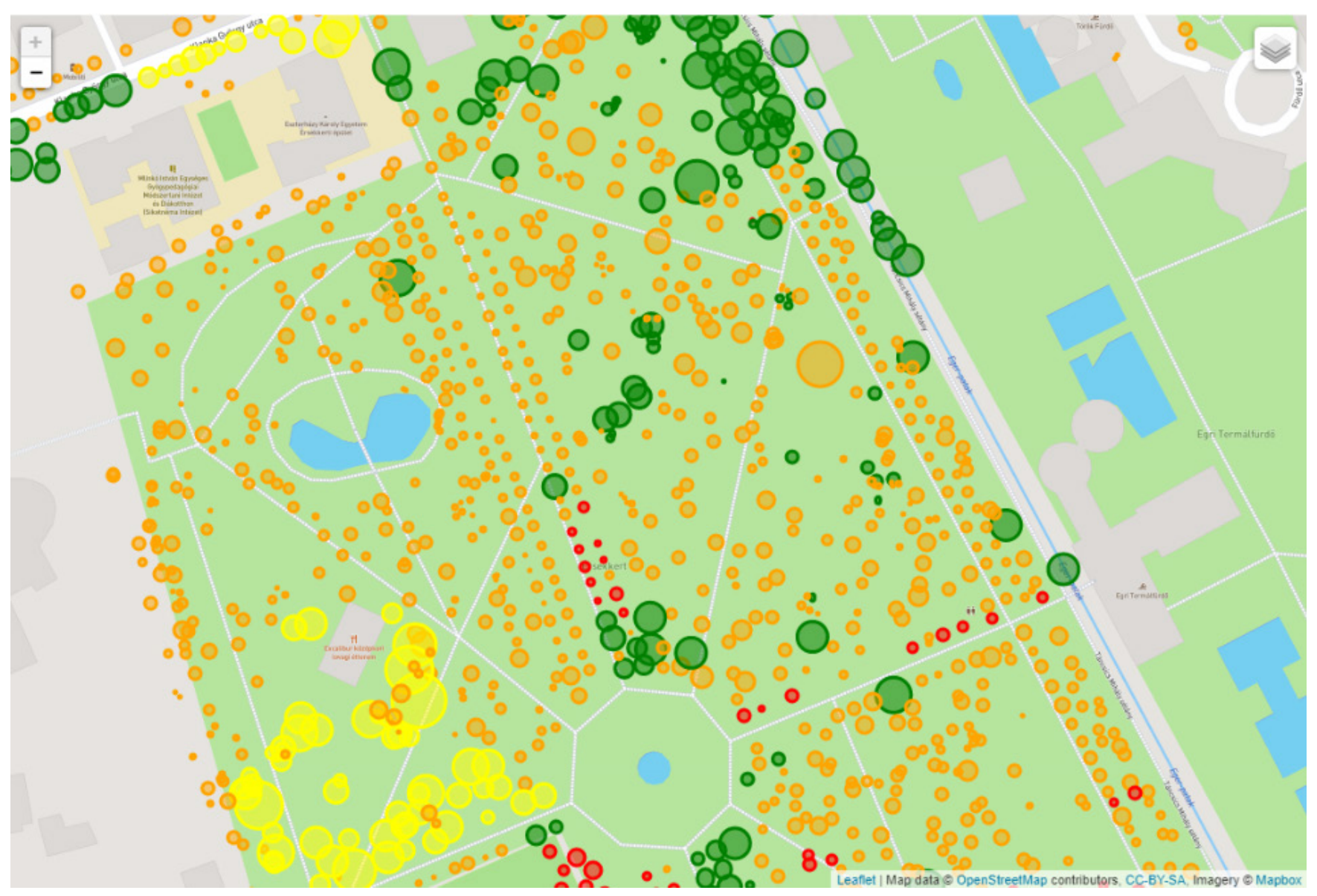

4. ábra: Részlet Eger város zöldterület minősítésére vonatkozó értékelésből. Az egyes színek a fák és cserjék potenciális allergenitása szerint vannak megadva.

Figure 4. A part of the evaluation of green area of Eger. Each colour is given according to the potential allergenicity of trees and shrubs, tree data from city cadastre. 
A fentiekben javasolt új zöldterület minősítési módszer a bevezetőben felsorolt követelményeknek eleget tesz, mivel:

- egyszerúen alkalmazható, ugyanis a meglévő fakataszterek alapján elvégezhető a felmérés. E módszerrel a zöldterületek minősítése a nyilvánosan hozzáférhető hazai kataszterek 100\%-ában elvégezhető.

- Nem jelentkeznek a növényzet helyszíni felmérésével járó többletfeladatok vagy költségek, nem kívánja meg külső szakterület szakembereinek bevonását, mivel a fakataszter adatbázishoz könnyen hozzáilleszthető a potenciális allergenitást tartalmazó adatsor,

- objektív, mivel pontos módszertani leírás alapján végezhető mind a parkok, mind a fasorok minősítése,

- alkalmas arra, hogy egy későbbi jogszabály alapját képezze.
A soron következő lépés tehát az, hogy az allergénterhelés csökkentése érdekében kialakítsuk a városi zöldterületek tervezésére, kialakítására vonatkozó szabályozást.

\section{További alkalmazási lehetőségek}

Az zöldterület minősítés eredménytérképe korszerü térinformatikai eszközökkel megjeleníthető, és továbbfejleszthető mobiltelefonos alkalmazássá, amely segítheti az allergiásokat a pollenadó források elkerülésében, a tünetek megelőzésében, így a személyre szabott medicina új eszköze lehet. További kutatások során érdemes lenne a minősítési kategóriák ellenőrzését is elvégezni különböző minősítésű zöldterületek közelében élő allergiások tüneteinek erősségét rögzítő kérdőív vagy tüneti napló elemzésével. 


\section{Köszönetnyílvánítás}

A szerzők köszönetüket fejezik ki Mányoki Gergelynek az 1. és 2. ábra elkészítésében való közreműködéséért.

\section{Nyilatkozatok}

A szerzők nyilatkoznak arról, hogy a közlemény más folyóiratban korábban nem jelent meg, és máshová beküldésre nem került. A szerzők nyilatkoznak arról is, hogy a cikk végleges változatát valamenynyi szerző elolvasta és jóváhagyta.

\section{Anyagi támogatás}

A módszer kidolgozását az EFOP1.8.0.-VEKOP-17-2017-00001 azonosítószámú, az „Egészségügyi ellátórendszer szakmai módszertani fejlesztése" címú kiemelt projekt biztosította.

\section{Szerzői érdekeltségek}

A szerzőknek nincsenek érdekeltségei.

\section{Irodalomjegyzék}

1. Cariñanos, P., Casares-Porcel, M., Quesada-Rubio, J-M.: Estimating the allergenic potential of urban green spaces: A case-study in Granada, Spain, Landscape Urban Planning, 123, 2014, 134- 144. https://doi.org/10.1016/j.landurbplan.2013.12.009

2. Cariñanos P., Adinolfi C., Díaz de la Guardia C: Characterization of Allergen Emission Sources in Urban Areas, J. Environ. Qual, 2016, 45:244-252. https://doi.org/10.2134/ jeq2015.02.0075

3. Samson, R., Ningal, T. F., Tiwary, A., Grote, R., Fares, S., Saaroni, H., Cariñanos, P., \& Järvi, L.: Species-specific information for enhancing ecosystem services. In The Urban Forest. Springer, Cham. 2017, 111-114, https://doi. org/10.1007/978-3-319-50280-9_12

4. Mányoki, G., Udvardy, O., Kajtor-Apatini, D., Orlóci, L., Magyar, D).: Budapesti kerékpárutak allergén pollenterhelése (Allergenic potential of tree lines along cycle tracks in $\mathrm{Bu}$ dapest). Egészségfejlesztés 2019, 60(4): 19-29.

5. Xu, J., Cai, Z., Wang, T., Liu, G., Tang, P., Ye, $X$. Exploring Spatial Distribution of Pollen Allergenic Risk Zones in Urban China. Sustainability, 2016, 8(10), 978, https://doi. org/10.3390/su8100978 
6. Cariñanos, P., Casares-Porcel, M., Díaz de la Guardia, C., Aira, MJ., Belmonte, J., Boi, M., Elvira-Rendueles, B., De Linares, C., Fernández-Rodriguez, S., Maya-Manzano, JM., Pérez-Badía, R., Rodriguez-de la Cruz, D., Rodríguez-Rajo, FJ., Rojo-Úbeda, J., Romero-Zarco, C., Sánchez-Reyes, E., Sánchez-Sánchez, J., Tormo-Molina, R., Ana M., Vega Maray:: Assessing allergenicity in urban parks: a nature-based solution to reduce the impact on public health. Environ Res, 2017; 155:219-227, https://doi.org/10.1016/j.envres.2017.02.015

7. Szaller, V.: Útmutató a fák nyílvántartásához és egyedi értékük kiszámításához. Magyar Faápolók Egyesületének kiadványa, 2012.

8. Magyar, D., Zséli, G., Szigeti, T., Páldy, A., Udvardy, O., Orlóci, L.: A növények potenciális allergenitása- áttekintés és módszertani javaslat. Egészégtudomány (in press), 2020.

9. Magyar, D., Gál, V., Jáki-Vékony, D., Szigeti, T. Hogyan válasszunk növényeket kertünkbe? Egészségtudomány, 2020, 64 (1-2), 95-96.
10. Arnold, E., Strohbach, MW., Warren, PS.: Allergenic potential of street trees in Boston, Massachusetts. in: Kabisch, N., Larondelle, N., \& Reeve, A. (Eds.). Human-environmental interactions in cities: Challenges and opportunities of urban land use planning and green infrastructure. Cambridge Scholars Publishing, 2014, 115-141.

11. Skjøth, C., Ørby, P. V., Becker, T., Geels, C., Schlünssen, V., Sigsgaard, T., ... \& Hertel, O.: Identifying urban sources as cause of elevated grass pollen concentrations using GIS and remote sensing. Biogeosciences, 2013, 10, 541-554. https://doi.org/10.5194/bg-10$\underline{541-2013}$

12. Szilágyi, A.: Eger város zöldterületének allergenitási vizsgálata térinformatikai eszközökkel. BSc. dolgozat, Szent István Egyetem, 2020. 